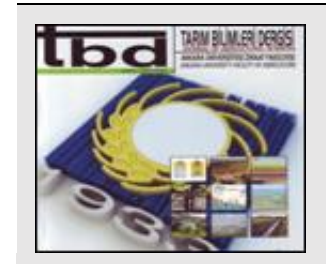

Tarım Bilimleri Dergisi Tar. Bil. Der.

Dergi web sayfasi: www.agri.ankara.edu.tr/dergi
Journal of Agricultural Sciences

Journal homepage:

www.agri.ankara.edu.tr/journal

\title{
Development and Analysis of a Belt Picking System for Sesame (Sesamum indicum L.) Harvesting
}

\author{
Selcuk UGURLUAY ${ }^{a}$, Gizem CARDAK ${ }^{\mathrm{a}}$ \\ ${ }^{\mathbf{a}}$ Hatay Mustafa Kemal University, Faculty of Agriculture, Department of Biosystems Engineering, Hatay, TURKEY
}

\author{
ARTICLE INFO \\ Research Article \\ Corresponding Author: Selcuk UGURLUAY, E-mail: ugurluay@ hotmail.com, Tel: +90 (326) 2455832 \\ Received: 19 April 2019, Received in Revised Form: 29 May 2019, Accepted: 29 May 2019
}

AUTHORS ORCID ID:

(Selcuk UGURLUAY: 0000-0003-4880-545X), (Gizem CARDAK:0000-0001-6568-8975)

\begin{abstract}
In this study, a picker system with a belt-pulley mechanism, which can be used in sesame harvesting only to aim grabbing the plant stems, was designed and manufactured. In addition, the optimum working criteria were determined in laboratory conditions. To this aim, catching efficiency of the picker was evaluated statistically depending on different pulley diameters $(155,185$ and $210 \mathrm{~mm})$, belt speeds $\left(0.55,0.66\right.$ and $\left.0.77 \mathrm{~m} \mathrm{~s}^{-1}\right)$ and belt gaps $(0$ and $5 \mathrm{~mm})$.
\end{abstract}

The catching efficiency increased as the pulley diameter, the belt speed and the belt gap increased. The picking system was found to be successful on catching the plant stems. Furthermore, the coefficient of friction between the plant body and the catching belt was determined according to the stem moisture content. As the stem moisture content decreased, a slight decrease was observed in the coefficient of friction between the belt material and the stem.

Keywords: Harvesting machinery; Picker set up; Sesame harvest; Uprooting resistance

\section{Introduction}

(C) Ankara Üniversitesi Ziraat Fakültesi

Sesame is one of the oldest annual plants cultivated in many parts of the world with tropical and subtropical climates, including India, Myanmar, Sudan and China (Yol 2011). It is an important industrial crop which contains 50-60\% oil and $20-30 \%$ protein in its seeds. Sesame oil is widely used in food, cosmetics, insecticides and soap industry. After removing the oil from the sesame seeds, $43 \%$ of the crude protein is present in the remaining cusps. For this reason, it has an important role in animal feed industry. Sesame residue is also considered as human food used as a joining material in breads in some countries (Hatipoğlu 2016).

In the world, 6.11 million tons of sesame seeds were produced on 10.57 million hectares of land with an average yield of $578 \mathrm{~kg} \mathrm{ha}^{-1}$ based on 2016 figures (FAO 2016). Main sesame importing countries in the world are China, Japan, EU countries and Turkey. There has been a decrease in sesame production in Turkey in recent years. The most important reasons for the decline of sesame agriculture in Turkey are the tendency of producers to turn to crops requiring less labor, the preference of crops that can be harvested mechanically, and the increase in labor costs due to the impossibility of mechanic harvesting. In fact, sesame agriculture offers a very profitable production with relatively low inputs, except for the labor costs. Moreover, if the progress in mechanical harvesting of sesame can be achieved, its cultivation as a second crop may be more prevalent (Arslan et al 2014).

Harvesting is still the most important problem in sesame cultivation since its harvest mainly depends on hand labor. Because of this, the harvest cost accounts for about $70 \%$ of the total cost of production (Dizdaroğlu \& Tan 1995). 
Sesame seeds reaching the maturity condition must be harvested in a timely and rapid manner. The delay in harvest time causes the capsules to lose moisture content and cracks resulting high harvest losses. For this reason, when the lower capsules reach the maturity, the harvesting should be started without waiting the upper capsules to reach full maturity.

In order to prevent seed losses, the plant is harvested by hand while being green. After it is gathered in the form of bundles, it is left to dry for 10 to 15 days. They are then turned back and threshed by hand or with a stick (Ugurluay 2002). Therefore, the mechanical harvesting of sesame is a necessity. As the days go by, most of the producers in Turkey are trying to stay away from labor intensive crops because of the difficulty of finding workers and increasing labor costs.

Harvesting of agricultural crops is generally done by machines which apply cutting-sawing, picking-shaking, shaking-vibrating or picking-collecting methods in many different ways (Ugurluay et al 2010). Vurarak et al (2017) tested a semi-mechanized harvesting method, which may be an alternative to manual harvesting in sesame cultivation. As a harvesting machine, a reaper with re-arranged mowing and binding units according to the technical specifications of sesame seeds was used. It was reported that semi-automatic harvesting can be offered as an alternative to the manual harvesting although it results in 7.5\% yield loss. Ugurluay (2008) developed a prototype harvester with belt-pulley mechanism for use in leek production and stated that this harvest head unit can also be used for similar in-row plants. Numerous studies have been carried out for plants such as lentils, peanuts, tubers, garlic, radishes, carrots and green onions that have been handcrafted at the harvest (Jun et al 2005; Geng 2008; Xiaoyan et al 2008; Zhichao et al 2008; Ranbing et al 2009; Deran et al 2010; Wei et al 2011; Jiasheng \& Shang 2012; Hong et al 2014).

In Turkey and in many other countries, sesame harvest is still heavily dependent upon hand labor. This study was carried out to determine some basic parameters leading to developing a harvesting machine that can be used to reduce the need for intensive labor in sesame harvesting. Harvesting sesame can be achieved by two methods: cutting or uprooting the stems. In this study, in order to harvest sesame based on uprooting method, an experimental picker set with a belt-pulley mechanism was designed, constructed and tested in laboratory conditions to determine its optimum operating criteria.

\section{Material and Methods}

In the study, Muganl1-57, which is a local sesame variety was used as plant material. Some properties of this variety were given in Table 1 (Tarimziraat 2017).

Table 1- Some vegetative properties of local variety of Muganlı-57

\begin{tabular}{ll}
\hline Vegetative properties & Values \\
\hline Length of the body & $80-150 \mathrm{~cm}$ \\
Shape of the stem & four corners \\
Color of the flower & white \\
Size of the capsule & $3-3.5 \mathrm{~cm}$ \\
Width of the capsule & $0.9 \mathrm{~cm}$ \\
Number of capsules in the plant & $70-140$ \\
Color of the grain & yellow-light brown \\
Yield & $600-1500 \mathrm{~kg} \mathrm{ha}^{-1}$ \\
\hline
\end{tabular}

The uprooting force of the plants from the soil was determined. The land on which the experiment was carried out had clayey-loamy soil. In order to determine the uprooting force of the sesame plants, 10 experiments were carried out. Sesame plant is a tap rooted plant but it is attached to the soil mainly by the fibrous roots. For this reason, soil humidity measurements were taken for the first $10 \mathrm{~cm}$ depth. In order to find the average uprooting force of the sesame plants, a force gauge (Geratech SH-500) with $500 \mathrm{~N}$ capacity and $0.1 \mathrm{~N}$ accuracy was used. The force gauge was connected to the plant body with a rope (Figure 1) and then an upward force was applied until the plant was removed from the soil. 


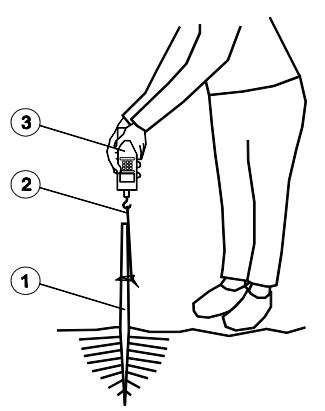

Figure 1- Measurements of the removal of sesame plants from the soil using the force meter $(1$, plant body; 2 , rope; 3 , force gauge)

The first step in sesame harvesting is picking of the sesame plants from the field. The belt-pulley mechanism was used in the part of the test set which will perform the picking work. A view of the experimental setup was given in Figure 2. Some of the sections on the experimental set were designed as adjustable to change and study some important parameters. These were the connection of the pulleys to the chassis, the reciprocal states of the belt-pulley pairs in the picker set and the revolutions of the electric motors.

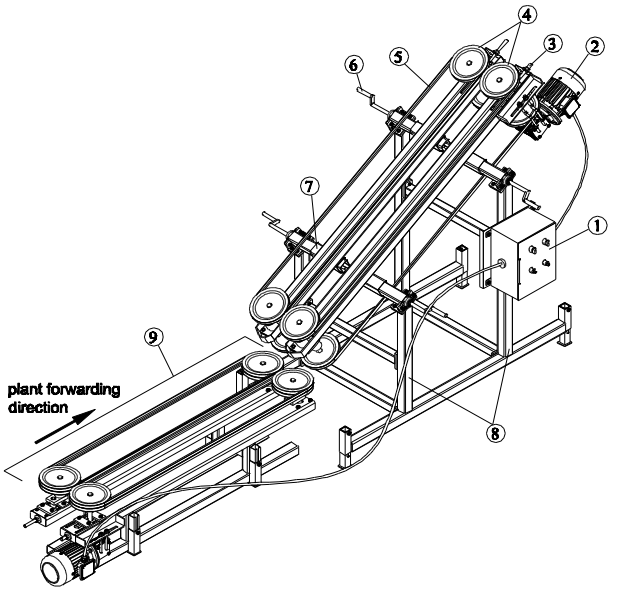

Figure 2- Isometric view of the test set (1, power and control panel; 2, electric motor; 3, belt tensioning setup; 4, pulleys; 5 , belts; 6 , adjustment lever; 7 , gap adjustment setup; 8 , frame; 9, plant transmission unit)

A digital speedometer (CEM AT-8) was used to adjust the speeds of the pulleys of the sesame harvest test apparatus. The accuracy of the speedometer was $0.1 \mathrm{~min}^{-1}$ and the measurement range was 2 to $10000 \mathrm{~min}^{-1}$.

In order to be able to pick up the plants using the belt-pulley system smoothly without any problems, it is necessary to know the working and design values such as the appropriate pulley diameter, belt speed and the gap between the belts. In the study, the design and operating criteria for the belt-pulley harvest head were determined. Different operating conditions were established in order to determine the appropriate catching criteria of the stems. In the tests, three independent variables namely, pulley diameters, belt speeds and gaps between belts were examined (Table 2 and Figure 3).

Table 2- Independent variables and its levels in the tests

\begin{tabular}{lr}
\hline Independent variables & Levels \\
\hline \multirow{2}{*}{ Pulley diameters (mm) } & $155(\mathrm{D} 1)$ \\
& $185(\mathrm{D} 2)$ \\
& $210(\mathrm{D} 3)$ \\
\hline \multirow{2}{*}{ Belt speeds $\left(\mathrm{m} \mathrm{s}^{-1}\right)$} & $0.55(\mathrm{~S} 1)$ \\
& $0.66(\mathrm{~S} 2)$ \\
& $0.77(\mathrm{~S} 3)$ \\
\hline \multirow{2}{*}{ Belt gaps $(\mathrm{mm})$} & $0(\mathrm{G} 1)$ \\
& $5(\mathrm{G} 2)$ \\
\hline
\end{tabular}




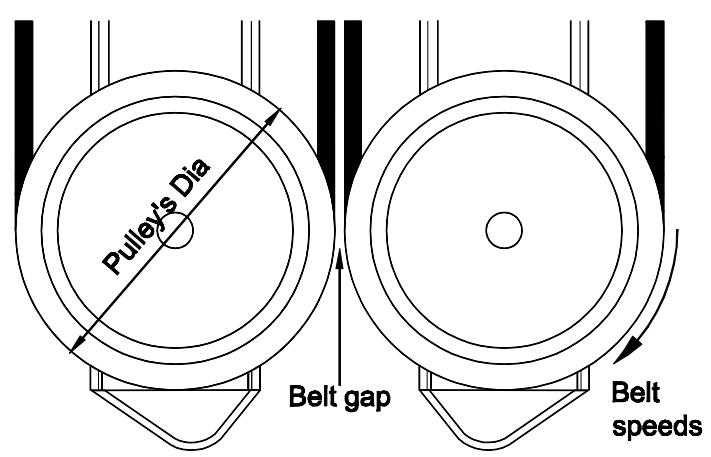

Figure 3- Independent variables in the study

Randomized block design with three replications were used in the tests. As a dependent variable, the catching efficiency (picker's efficiency for grabbing the plants) was evaluated. The data obtained from the trials were analyzed in a statistical package program (SPSS-Statistical Package for the Social Sciences) (Version: 14.0, IBM, Armonk, NY, USA).

For determining the appropriate pulley diameters, the physical dimensions (profile widths, minimum and maximum limits of the range setting mechanism, etc.) of the picker test set were taken into consideration. Belt velocities were chosen according to the machine feed rate, assuming that the harvester experiment set was a harvest head superimposed on the tractor. It was assumed that the speed of progression of the tractor with such a harvest setup would be $2.0-2.5 \mathrm{~km}$ $\mathrm{h}^{-1}\left(0.55 \mathrm{~m} \mathrm{~s}^{-1}\right)$ which could be considered as an average speed of a harvesting machinery (For example; sugar beet and potato harvesters). The $1^{\text {st }}$ speed was chosen to be the same as the tractor feed rate, the $2^{\text {nd }}$ speed $20 \%$ more than the speed of the tractor $\left(0.66 \mathrm{~m} \mathrm{~s}^{-1}\right)$, and the $3^{\text {rd }}$ speed $40 \%$ more than the tractor speed $\left(0.77 \mathrm{~m} \mathrm{~s}^{-1}\right)$.

The stems were caught between the belts. The mean body thickness of sesame plants which reached harvesting stage is reported as $10.4 \mathrm{~mm}$ (Ugurluay 2002). According to this data, catching tests were performed based on two gaps where the belts were in full contact ( $0 \mathrm{~mm}$ distance) and the belts were slightly spaced ( $5 \mathrm{~mm}$ distance).

One of the parameters affecting the catching efficiency is the friction coefficient between the belt and the stem. The inclined plane method was used to find the static friction coefficient between the plant stem and the v-belts. The inclined plane consisted of two parts; a horizontal and fixed plane and an inclined plane connected by a hinge (Figure 4). The effect of moisture values on friction coefficient was investigated by using One-Way ANOVA test at $\mathrm{P}=0.05$ significance level.

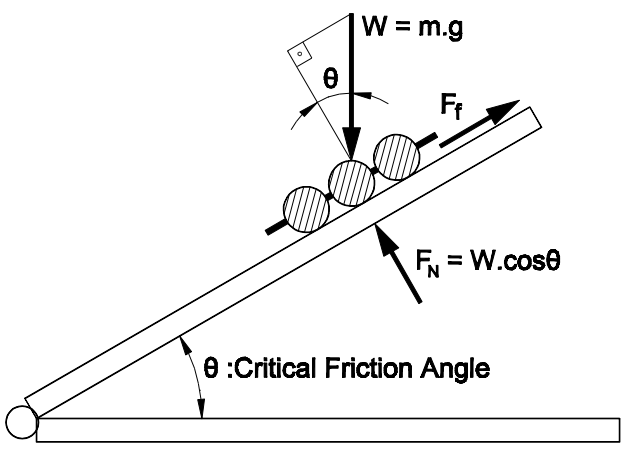

Figure 4- Determination of friction angle by inclined plane method

The v-belt pieces were placed and stuck at regular intervals on the inclined plane. During the tests, an angle meter was used to determine the angles $(\theta)$ in the inclined plane. To prevent rolling of the stems on the inclined plane and to allow them to move by sliding, three plants were connected to each other by using wires (Figure 4). Plant stems were placed at the beginning of the v-belts and the inclined plane was slowly moved upwards. At that moment when the stems started to slip, the oblique plane was stopped and the angle made with the horizontal plane was measured. To 
obtain the friction coefficient $(\mu)$, the tangents of the angles obtained in the experiments were calculated. The experiments were carried out in 3 replicates. The arithmetic mean of the values was taken. Equation 1 was used to obtain the friction coefficient $(\mu)$.

$\tan \theta=\frac{F_{f}}{F_{N}}=\mu$

Where; $F_{f}$, friction force, $\mathrm{N} ; F_{N}$, normal force, $\mathrm{N} ; \mu$, coefficient of friction

A drying oven was used to determine the moisture content of the plant material. A precision scale with a sensitivity of $0.01 \mathrm{~g}$ (Sartorius GP 3202, Gottingen, Germany) is used for material weighing. The relationship between moisture content and friction coefficient in the stem was also investigated. For this aim, twelve plant specimens were divided into groups of two $(n=6)$. Using a pair of plant stems (Group 1), inclined plane experiments were carried out in 3 replicates for 4 days to study the effect of the moisture content on the friction. The remaining 5 groups of plants were used to measure the change in moisture content during the 4 days. Then, average values were calculated and used in data analysis. In order to determine the moisture content, the wet mass values of the plant samples were recorded using sensitive scales. The weighed samples were dried in a drying oven at $105^{\circ} \mathrm{C}$ for 24 hours, after which the masses were again measured. Moisture ratios of plant samples were calculated using Equation 2 (Mohsenin 1970).

$M_{R}=\frac{\left(W_{m}-D_{m}\right)}{W_{m}} \times 100$

Where; $M_{R}$, moisture ratio (\%); $W_{m}$, wet mass $(\mathrm{g}) ; D_{m}$, dry mass $(\mathrm{g})$

The normal force $\left(F_{N}\right)$ that allows the pulleys to clamp and hold the plant stems was measured with a force gauge. Using Equation 3, the frictional force between the belt and the plant stem was calculated.

$F_{f}=F_{N} \cdot \mu$

The frictional force $\left(F_{f}\right)$ is equal to the maximum holding force $\left(F_{h}\right)$. In Figure 5, the forces that occur on the plant stem during the grabbing was shown.

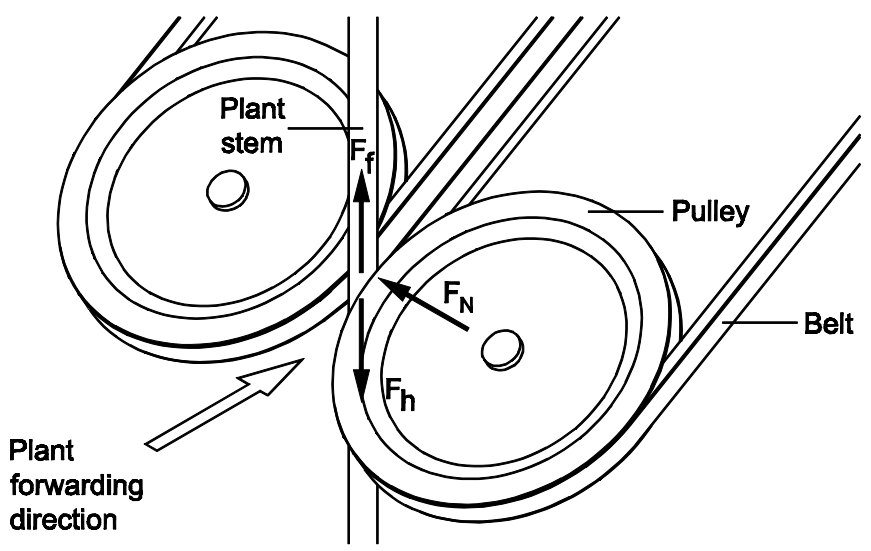

Figure 5- The forces on the plant stem during the grabbing

\section{Results and Discussion}

As a result of the literature search, no study was found similar to the subject of the current study. The only known and similar work was carried out by Ugurluay (2008) on a prototype harvester that can be used in leek harvesting. In this study, the uprooting conditions were investigated because of the necessity of harvesting the leek plant. A picker unit 
with wide belts and pulleys was designed. The plant uprooting forces were measured, found to be quite big, and a knife was used to move under the ground to loosen the root zone.

Another similar study was carried out by Yumak \& Evcim (1990). They developed a prototype "two-row cotton stalk pulling machine" to mechanically pull up the cotton stalks after harvesting. It was reported that the machine removed plant stalks from the soil in good conditions up to $95 \%$.

In this study, a double row picking unit with narrow belts and pulleys was designed to suit sesame plant structure. The uprooting conditions have been examined. The plant uprooting strength was measured. The average value of the coefficient of friction between the plant and the picker belts was determined. It has been tried to calculate which values the friction force can reach. The effect of the moisture content on the coefficient of friction between the stem and the belt was shown as a graph in Figure 6.

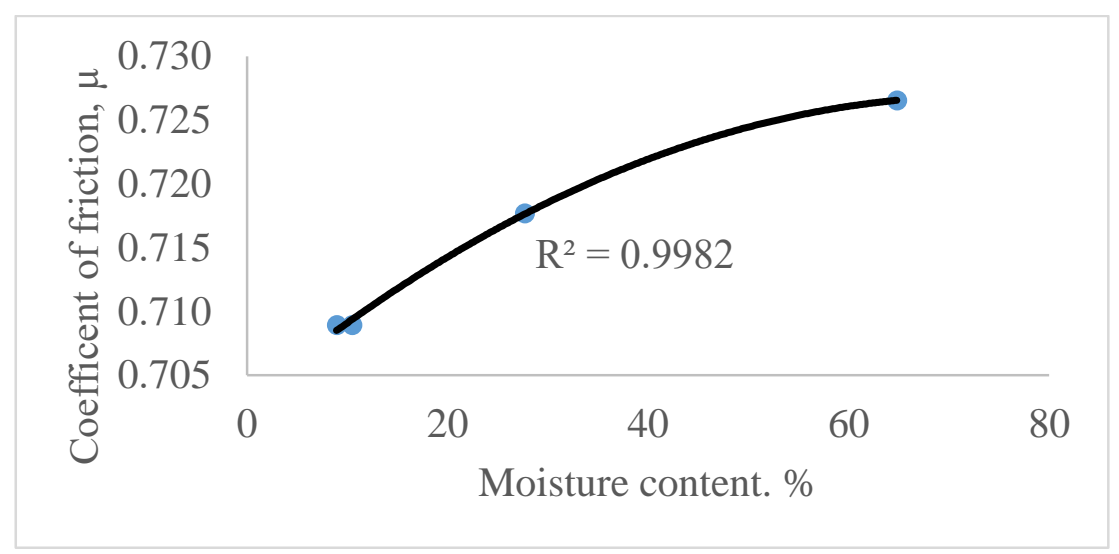

\section{Figure 6- Relation graph between moisture change and coefficient of friction}

A slight decrease in friction coefficient values was observed as the moisture content of the stems decreased. Statistically, the effect of moisture values on friction coefficient values was not significant $(\mathrm{P}>0.05)$.

Based on the results of the uprooting force test it was found that the stalk diameter was $13.7 \pm 1.1 \mathrm{~mm}$, the uprooting force was $309.1 \pm 64.9 \mathrm{~N}$, the soil moisture content (\%) was $23.56 \pm 0.55$. The grip strength of the plant stems between the belts was calculated as $200 \mathrm{~N}$ on average. It was found that this value was much lower than the plant uprooting force. The finding of the uprooting force as much greater than the grip strength suggested that the plants must be cut from the bottom with a knife or the root zone must be loosened during harvesting.

The picker experimental set was created in two parts as previously mentioned. The first part was used only to transfer the sesame plants to the picker. In the experiments, 30 plants were fed by hand to the conveyor belt to send them to the picker set. Plants conveyed by the conveyor belt were expected to be captured by the picker (Figure 7).

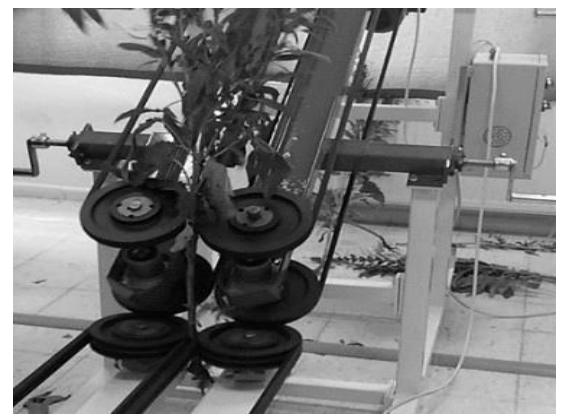

Figure 7- Grabbing the sesame plant of the picker set

The variance analysis results are given in Table 3 and the Duncan Test results are given in Table 4. When the variance analysis table was examined, the pulley diameters, belt speeds and belt gaps were found to be important in 
terms of catching the plant stalks. In the catching event, the pulley diameter and the belt speed were found to be insignificant in the dual interactions of variation sources. Belt speed and belt gap and pulley diameter and belt gap interactions were found significant. That is to say, when the belt speed-the belt gap and the belt diameter-the belt gap are evaluated together, there was a difference in the catching efficiency between them. Interaction analysis revealed that $2^{\text {nd }}$ belt gap value $(5 \mathrm{~mm})$ gave better results.

Duncan comparison test results (Table 4) revealed that the $1^{\text {st }}$ pulley diameter $(155 \mathrm{~mm})$ and the $2^{\text {nd }}$ pulley diameter $(185 \mathrm{~mm})$ were similar while the $3^{\text {rd }}$ pulley diameter $(210 \mathrm{~mm})$ was found to be different from the other two at the significance level of 0.001 when the pulleys used in the test apparatus were evaluated for the ratio of catching sesame plants. Therefore, the $3^{\text {rd }}$ pulley diameter value $(210 \mathrm{~mm})$ was found to be much more successful than the other two pulley diameters in terms of catching ratio. The $3^{\text {rd }}$ belt speed value $\left(0.77 \mathrm{~m} \mathrm{~s}^{-1}\right)$ was the most successful when the belt speeds used in the test apparatus were evaluated for the ratio of catching sesame plants. The $1^{\text {st }}$ band speed value $(0.55$ $\left.\mathrm{m} \mathrm{s}^{-1}\right)$ gave the lowest catching ratio. The ratio value of the $2^{\text {nd }}$ band speed value $\left(0.66 \mathrm{~m} \mathrm{~s}^{-1}\right)$ was in the middle. It was found to be similar to both the $1^{\text {st }}$ one and $3^{\text {rd }}$ one. The difference between the $1^{\text {st }}(0 \mathrm{~mm})$ and the $2^{\text {nd }}$ gap value $(5 \mathrm{~mm})$ was statistically significant and the $2^{\text {nd }}$ gap $(5 \mathrm{~mm})$ was found to be much more successful when the band gaps used in the experiment were evaluated for the ratio of catching sesame plants.

Table 3- The variation analysis results

\begin{tabular}{lrcrc}
\hline Variation sources & $\begin{array}{r}\text { Sum of } \\
\text { squares }\end{array}$ & $\begin{array}{c}\text { Degree of } \\
\text { freedom }\end{array}$ & $\begin{array}{c}\text { Squares } \\
\text { average }\end{array}$ & $F$ \\
\hline General & 149333 & 53 & & \\
Diameter & 23111 & 2 & 11556 & 0.000 \\
Speed & 9000 & 2 & 4500 & 0.008 \\
Gap & 42667 & 1 & 42667 & 0.000 \\
Diameter * Speed & 6556 & 4 & 1639 & 0.114 \\
Speed * Gap & 9000 & 2 & 4500 & 0.008 \\
Diameter * Gap & 23111 & 2 & 11556 & 0.000 \\
Diameter * Speed * Gap & 6556 & 4 & 11556 & 0.114 \\
Error & 29333 & 36 & 1639 & \\
\hline
\end{tabular}

Table 4- The catching success of the belt picking system based on different parameters

\begin{tabular}{llllll}
\hline $\begin{array}{l}\text { Pulley } \\
\text { Diameter }(D)\end{array}$ & $\begin{array}{l}\text { Catching } \\
\text { Ratio }\end{array}$ & Belt speed & $\begin{array}{l}\text { Catching } \\
\text { Ratio }\end{array}$ & Belt gap & $\begin{array}{l}\text { Catching } \\
\text { Ratio }\end{array}$ \\
\hline D1 28.4 $\pm 2.04^{\mathrm{a}}$ & $94.7 \%$ & $\mathrm{~S} 128.6 \pm 2.09^{\mathrm{a}}$ & $95.6 \%$ & $\mathrm{G} 128.2 \pm 2.02^{\mathrm{a}}$ & $94.0 \%$ \\
$\mathrm{D} 228.9 \pm 1.81^{\mathrm{a}}$ & $96.3 \%$ & $\mathrm{~S} 229.1 \pm 1.81^{\mathrm{ab}}$ & $97.0 \%$ & $\mathrm{G} 230.0 \pm 0.00^{\mathrm{b}}$ & $100.0 \%$ \\
$\mathrm{D} 330.0 \pm 0.00^{\mathrm{b}}$ & $100.0 \%$ & S3 29.6 $\pm 0.78^{\mathrm{b}}$ & $98.7 \%$ & & \\
$\mathrm{P}<0.001$ & & $\mathrm{P}<0.01$ & & $\mathrm{P}<0.001$ & \\
\hline
\end{tabular}

Values are mean \pm s. e.; $a, b$ with the same superscript indicate no significant difference in the same column

\section{Conclusions}

The harvesting system with belt pulleys was found to be successful in the grabbing of sesame plants. As a result of the obtained data, such a collecting system can be used on a machine designed for sesame harvesting. The plant's uprooting force from the soil was measured and it was not possible to remove it directly with a harvesting head with belt pulley mechanism. For this reason, it is necessary to either loosen the root zone of the plant by using the underground knives or cut off the plant stem during the catching with a knife mechanism.

\section{Acknowledgements}

This publication was produced from a master's thesis. This research was supported by Hatay Mustafa Kemal University Office of the Scientific Research Projects (No: 15520).

\section{References}

Arslan H, Hatipoğlu H \& Karakuş M (2014). Determination of yield and yield components as a second crop of some sesame genotypes collected from Şanliurfa region. Turk Journal of Agricultural Research 1: 109-116 ISSN: 2148-2306. (In Turkish) 
Deran L, Yanyao W, Xunjin W, Yundong L \& Zhirui X (2010). Manufacture and Exploiture of 4s-6 Type Garlic Harvester. Journal of Agricultural Mechanization Research 2010-04. pp. 96-98

Dizdaroğlu T \& Tan Ş (1995). In Aegean Region under Watery and Dry Conditions II. Product Sesame Production and Problems. Anadolu Yayınevi, Menemen, İzmir ISSN: 1300-0225 (In Turkish), 5(1): 48-73

FAO (2016). The Food and Agriculture Organization of the United Nations. http://faostat3.fao.org/download/Q/QC/E (Date of access: 10.04.2018)

Geng D (2008). Design and study on the horizontal double rollers peanut stripper. Journal of Agricultural Mechanization Research (1): $98-101$

Hatipoğlu H (2016). Determining the yield and yield components of some sesame (Sesamum Indicum l.) cultivars under Siirt second crop conditions. MSc Thesis. University of Siirt, Institute of Science and Technology, Siirt, Turkey. (unpublished), (In Turkish)

Hong S, Lee K, Cho Y \& Park W (2014). Development of Welsh Onion harvester for tractor. Journal of Biosystems Engineering 39(4): 290-298

Jiasheng W \& Shang S (2012). Development and experiment of double-row self-propelled carrots combine. Transactions of the Chinese Society of Agricultural Engineering

Jun H J, Kim S H, Hong J T \& Choi Y (2005). Cutting and conveying characteristics for development of Chinese leek harvester. Korean society for agricultural machinery. Journal of Biosystems Engineering 30(4): 220-228

Mohsenin N N (1970). Physical Properties of Plant and Animal Materials. Gordon and Breach Science Publisher, 742 pp, New York

Ranbing Y, Yufeng X, Shuqi S, Jie L, Guoying L \& Tongzhen S (2009). Design and comparative test of removing-soil device of peanut combine harvester. Journal of Agricultural Mechanization Research

Tarimziraat (2017). Properties of Muganli-57 Sesame Variety. (In Turkish) www.tarimziraat.com/tarim_urunleri/cesit_detay/40_1724/muganli-57susam-tohumu-cesidi-ozellikleri (Date of access: 10.12.2017)

Ugurluay S (2002). A research on determination of harvesting mechanization possibilities of sesame plant. MSc Thesis, University of Cukurova, Institute of Science and Technology, Agricultural Machinery, Adana, Turkey. (In Turkish), 51 pp

Ugurluay S (2008). Determination of technique achievements in some vegetables harvesting in Cukurova region and developing of prototype leek harvester. PhD Thesis, University of Cukurova, Institute of Science and Technology, Agricultural Machinery Master of Science, Adana, Turkey, 196 pp (In Turkish)

Ugurluay S, Ince A, Sessiz A, Kayisoglu B, Guzel E \& Ozcan M T (2010). Hasat Harman Makinalarl ve Illkeleri. Nobel Kitabevi. 316 pp. (In Turkish)

Vurarak Y, Bilgili M \& Angin N (2017). Determination of effects of different harvest method on yield and some operating running parameters of main crop sesame. University of Uludag, Journal of Agricultural Faculty, 31(2): 1-9

Wei F, Haitao C \& Za K (2011). Optimizing parameters on vibration break shovel of radish harvester. Transactions from the Chinese Society of Agricultural Engineering 27(11): 46-50

Xiaoyan W, Jie L, Shuqi S, Jingtao J \& Ranbing Y (2008). Design and experiment of half feeding type peanut picker. Transactions from the Chinese Society of Agricultural Engineering 24(9): 94-98

Yol E (2011). Identification of genetic diversity and characterization of world sesame collection for agro-morphological and quality characters. MSc Thesis, University of Akdeniz, Institute of Science and Technology, Field Crops, Antalya, 89 pp

Yumak H \& Evcim Ü (1990). A Two-Row Cotton Stalk Pulling Machine. International Congress on Mechanization and Energy in Agriculture. Proceedings of a conference held in Adana, Turkey, 1-4 October 416-425 pp

Zhichao H, Baoliang P, Wenqing Y, Haiou W, Fulai J \& Huanxiong X (2008). Design and experiment on multifunctional root-tuber crops combine. Transactions of the Chinese Society for Agricultural Machinery 